\title{
Aquatic insect communities in headwater streams of Ciliwung River watershed, West Java, Indonesia
}

\author{
WAKHID $^{1, \vartheta}$, AUNU RAUF ${ }^{2, v \vartheta}$, MAJARIANA KRISANTI ${ }^{3}$, I MADE SUMERTAJAYA $^{4}$, NINA MARYANA ${ }^{2}$ \\ ${ }^{1}$ Program of Entomology, Graduate School, Institut Pertanian Bogor. Jl. Kamper, IPB University Campus Dramaga, Bogor 16680, West Java, Indonesia. \\ Tel.: +62-251-8629364, Fax.: +62-251-8629362, "email: wakhid.doank@yahoo.com \\ ${ }^{2}$ Department of Plant Protection, Faculty of Agriculture, Institut Pertanian Bogor. Jl. Kamper, IPB University Campus Dramaga, Bogor 16680, Indonesia. \\ Tel.: +62-251-8629353, Fax.: +62-251-8629353, • email: aunu@indo.net.id \\ ${ }^{3}$ Department of Aquatic Resources Management, Faculty of Fisheries and Marine Sciences, Institut Pertanian Bogor. Jl. Agatis, IPB University Campus \\ Dramaga, Bogor 16680, Indonesia \\ ${ }^{4}$ Department of Statistics, Faculty of Mathematics and Natural Sciences, Institut Pertanian Bogor. Jl. Meranti, IPB University Campus Dramaga, Bogor \\ 16680, Indonesia
}

Manuscript received: 11 October 2020. Revision accepted: 8 December 2020.

\begin{abstract}
Wakhid, Rauf A, Krisanti M, Sumertajaya IM, Maryana N. 2021. Aquatic insect communities in headwater streams of Ciliwung River watershed, West Java, Indonesia. Biodiversitas 22: 30-41. Ciliwung is one of the major rivers flowing from Cisarua (Bogor) to Jakarta. This study was conducted to assess and compare aquatic insect biodiversity and community structure in various headwater streams with respect to different land-use types. Ten stream reaches of the first and second orders representing three different land-use types in the surrounding area (forest, tea plantation, village) were selected. At each stream reach, the aquatic insects were collected using a D-net ( $0.4 \mathrm{~mm}$ mesh). Physico-chemical properties of water were directly measured in the field. Samples were collected every two months from April until December 2018. A total of 26531 aquatic insect specimens belonging to 75 species/morphospecies, 46 families, and 10 orders were recorded. The order Trichoptera was the most abundant comprising $51.28 \%$ of the total collected insects, followed by Diptera (30.5\%), Ephemeroptera (7.52\%), and Plecoptera (6.25\%). The highest proportion of functional feeding group was filteringcollectors $(61.34 \%)$, followed by shredders $(16.29 \%)$, gathering-collectors $(15.32 \%)$, and predators $(6.94 \%)$. Abundance of Diptera and Plecoptera was significantly higher in forest streams, while Ephemeroptera in plantation streams, and Trichoptera in village streams. The peak population of Diptera, Ephemeroptera, and Trichoptera occurred in June (dry period), while Plecoptera in December (wet period). The forest streams exhibited the highest species richness and diversity. Analysis of similarity (ANOSIM) showed a low dissimilarity among streams of the three land uses (Global $\mathrm{R}=0.217 ; \mathrm{P}<0.001)$. The non-metric multidimensional scaling (NMDS) analysis showed that forest streams somewhat separated from plantation and village streams. The study provided important information on aquatic insect biodiversity, and indicated the need for forest area preservation in the headwater streams of Ciliwung River watershed.
\end{abstract}

Keywords: Aquatic insects, biodiversity, Ciliwung, community structure

\section{INTRODUCTION}

Headwater streams are major components of river networks because they make up more than three-quarters of channel length in watersheds (Clarke et al. 2008). Despite their proportion, they are only recently becoming more recognized as ecologically significant river areas (Santos and Stevenson 2011). Furthermore, headwater streams offer vital services to humankind, namely the storage, regulation, and purification of water (Bucker et al. 2010). All these services depend on healthy ecosystems that are currently endangered by degradation (Edia et al. 2016). Although, headwater streams may be small in size, they provide habitats for a rich array of species, which enhances the biological diversity of the entire river system (Meyer et al. 2007). As a unique ecosystem with many specialist species, these streams deserve better stewardship (Richardson 2019). Also, headwater streams provide the in-stream processing of nutrients and energy from nearby riparian input which are transferred to downstream systems. Therefore, headwaters may be vital for maintaining the function and health of whole river networks, and they are important areas for maintaining biodiversity (Clarke et al. 2008). In addition, water quality, biodiversity, and ecological health of a freshwater ecosystem depend on natural functions of the headwaters (Abell et al. 2019).

Among aquatic organisms, insects stand out in ecological analysis due to their high diversity and abundance (Dijkstra et al. 2014; Koroiva and Pepinelli 2019), broad distribution, and key roles in trophic webs (Morse 2017; Cummins 2018). Furthermore, insects are essential for the energy flux between aquatic and terrestrial ecosystems, as their life cycle comprises a juvenile aquatic and an adult terrestrial stage (Wesner 2010). Tropical streams in Asia are known to constitute rich habitats for diverse groups of freshwater organisms, including aquatic insects. Meanwhile, studies in Vietnam (Jung et al. 2008), Malaysia (Al-Shami et al. 2013; Wong and Fikri 2016; Muli et al. 2019), and Thailand (Maneechan and Prommi 2015) showed that tropical streams evidenced a high degree of aquatic insect diversity. The community structure in lotic environment is directly related to substrate, temperature, dissolved oxygen, geomorphologic and biological interactions, riparian vegetation and seasonality, food resources, microhabitats, 
habitat heterogeneity, physical and chemical variables, water quality, and land use (Hepp et al. 2013; Narangarvuu et al. 2014; do Amaral et al. 2015; Koroiva and Pepinelli 2019). Those characteristics vary in time and space, therefore, it is expected that the variations will determine the spatial and temporal changes of diversity and structure of animal aquatic communities (Braun et al. 2014).

The Ciliwung River is the largest and the most important of thirteen rivers flowing through the coastal region of Jakarta, with a length from upstream to the estuary of approximately $117 \mathrm{~km}$ and a cover area of 387 $\mathrm{km}^{2}$. Furthermore, the catchment area of this river is originated from the slope of Gede-Pangrango Mountain (3000 $\mathrm{m}$ above sea level) of West Java. Taking into account that biodiversity knowledge of a region is the first step toward its conservation (Edia et al. 2016) and given the paucity of studies on aquatic insects from streams and rivers in Indonesia, this study aims to assess and compare aquatic insect biodiversity and community structure in various headwater streams with different land use patterns (forest, tea plantation, village). Therefore, the results are expected to provide baseline information on which to build suggestions to advance the conservation efforts.

\section{MATERIALS AND METHODS}

\section{Study area and sampling sites}

The study area was in the headwater streams of Ciliwung River watershed, located in Cisarua, Bogor, with an altitude of 1400-1500 $\mathrm{m}$ above sea level (Figure 1). The annual rainfall averaged $1125 \mathrm{~mm}$, and the mean temperature in the warmest month (May) was $21.3{ }^{\circ} \mathrm{C}$ and in the coldest (January) $19.6{ }^{\circ} \mathrm{C}$. Ten stream reaches, belonging to first and second-order streams and representing three different land-use types in the surrounding area, were selected (Table 1). Four stream reaches (F1, F2, F3, F4) were surrounded by relatively undisturbed moist montane forest, and three reaches (P1, $\mathrm{P} 2$, P3) surrounded by tea plantations. The other three reaches $(\mathrm{V} 1, \mathrm{~V} 2, \mathrm{~V} 3)$ of the second-order stream were surrounded by the villages.

Table 1. Characteristics of the headwater streams studied in the Ciliwung River watershed, West Java, Indonesia

\begin{tabular}{|c|c|c|c|c|}
\hline $\begin{array}{c}\text { Stream } \\
\text { reach }\end{array}$ & Land use & Coordinate & $\begin{array}{c}\text { Alt. } \\
\text { (m asl.) }\end{array}$ & $\begin{array}{c}\text { Stream } \\
\text { order }\end{array}$ \\
\hline F1 & Forest & $6^{\circ} 40^{\prime 2} 21.85 " \mathrm{~S} 106^{\circ} 59^{\prime 2} 28.05^{\prime \prime} \mathrm{E}$ & 1521 & $1 \mathrm{st}$ \\
\hline $\mathrm{F} 2$ & Forest & $6^{\circ} 40^{\prime} 25.61 " \mathrm{~S} 106^{\circ} 59^{\prime} 24.85^{\prime \prime} \mathrm{E}$ & 1515 & $1 \mathrm{st}$ \\
\hline F3 & Forest & $6^{\circ} 40^{\prime} 30.31 " \mathrm{~S} 106^{\circ} 59^{\prime 2} 23.48^{\prime \prime} \mathrm{E}$ & 1507 & $1 \mathrm{st}$ \\
\hline F4 & Forest & $6^{\circ} 41^{\prime} 45.96 " \mathrm{~S} 106^{\circ} 59^{\prime} 43.14 \mathrm{E}$ & 1468 & $1 \mathrm{st}$ \\
\hline P1 & Tea plantation & 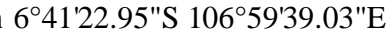 & 1441 & $1 \mathrm{st}$ \\
\hline P2 & Tea plantation & $6^{\circ} 41^{\prime 2} 22.54^{\prime \prime S} 106^{\circ} 59^{\prime} 35.72 " \mathrm{E}$ & 1439 & 1 st \\
\hline P3 & Tea plantation & $6^{\circ} 41^{\prime 2} 21.47^{\prime \prime S} 106^{\circ} 59^{\prime} 32.58^{\prime \prime E}$ & 1435 & $1 \mathrm{st}$ \\
\hline V1 & Village & $6^{\circ} 41^{\prime} 17.48^{\prime \prime S} 106^{\circ} 59^{\prime} 24.07^{\prime E}$ & 1430 & 2nd \\
\hline $\mathrm{V} 2$ & Village & $6^{\circ} 41^{\prime} 16.44 " \mathrm{~S} 106^{\circ} 59^{\prime 2} 20.78^{\prime \prime E}$ & 1423 & 2nd \\
\hline V3 & Village & 641'19.38"S 10659'19.39"Е & 1418 & 2nd \\
\hline
\end{tabular}

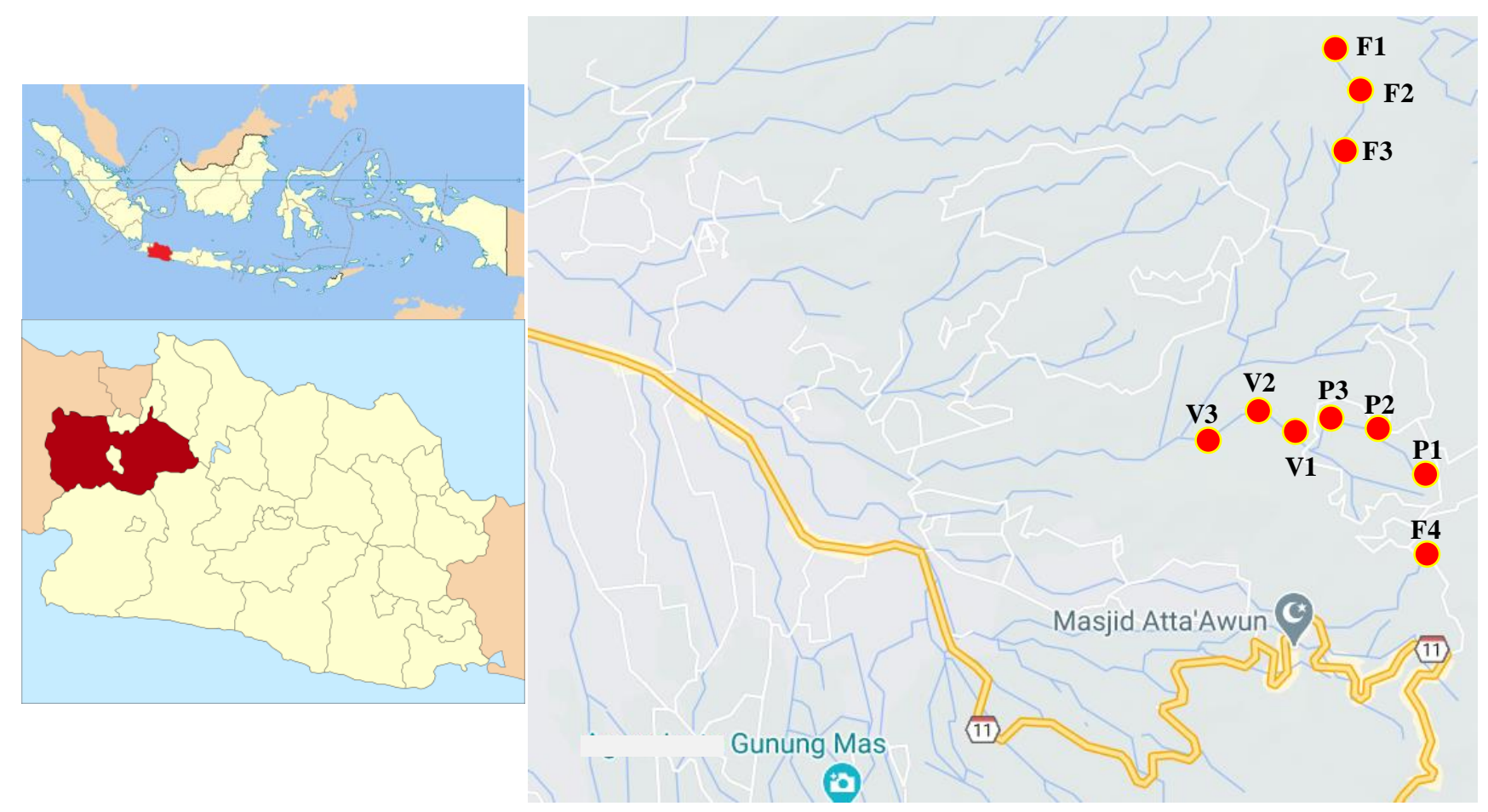

Figure 1. Map of the headwater streams studied in the Ciliwung River watershed, West Java, Indonesia. Note: F: Forest, P: Tea plantation, V: Village 


\section{Aquatic insect sampling and measurement of water physicochemical properties}

Aquatic insect sampling was conducted between 08.00 am to $03.00 \mathrm{pm}$ in April, June, August, October, and December 2018. In each stream, within a stretch of approximately $20 \mathrm{~m}$ length, ten sub-samples were collected approximately $1 \mathrm{~m}$ apart from a mixture of different habitats (riffle, run, pool). Furthermore, a D-shaped net (40 $\mathrm{cm}$ width, $400 \mu \mathrm{m}$ mesh size) was used to sample aquatic insects. The kick sampling technique was applied for collection in the riffle and run areas, meanwhile, one meter square areas in the front of the net were disturbed for 2 minutes. Insects in pool sections were collected by dragging the net through the water when the bottom substrates were disturbed for two minutes, following Wong and Fikri (2016). Insects caught in the net were collected and placed in vial bottles containing $96 \%$ ethanol. Subsequently, the insects were identified up to the lowest taxonomic categories from available references (Morse et al. 1994; Cheng et al. 2001; Yule and Sen 2004; Mekong River Commission 2006; Polhemus and Polhemus 2013). Taxa without taxonomic references to species level, which describes the majority of the cases in this study, were separated into morphospecies, primarily based on external ultrastructures.

The selected physicochemical properties of stream water including temperature, $\mathrm{pH}$, dissolved oxygen (DO), turbidity, current velocity, and channel width were recorded. Water temperature and $\mathrm{pH}$ were measured using a thermo-pH meter (ADWA AD-12), while DO was measured using a DO meter (Lutron 5510), and turbidity through a turbidity meter (HACH 2100Q).

\section{Data analysis}

One-way analysis of variance (ANOVA) was conducted to test significant differences in environmental variables between land use types using SPSS version 22 . Principal component analysis (PCA) was applied to evaluate the stream ordination of different land-use types with respect to the environmental variables. The vector length represents the strength of the environmental factor correlation with a particular direction or gradient. The abundance of aquatic insects was tabulated for each land use, and functional feeding groups (FFG) were classified according to Cummins (2018). Shannon-Wiener diversity index was computed for the land use types as $\mathrm{H}^{\prime}=$ Epi.Inpi. Differences in the Shannon-Wiener diversity indices of aquatic insects in each land use were explored by applying Hutcheson t-tests. PCA, diversity indices, and ttests analyses were carried out in PAST 3.10 program (Hammer et al. 2001).

Repeated-measures analysis of variance (ANOVA) was performed using SPSS version 22 to analyze the effects of land-use types on the abundance of major aquatic insect orders. Sampling dates were included as replication levels. Abundance data of aquatic insects were log-transformed before analyses to ensure normality and equal variances, and Levene's test of equality for error variances and asymmetry was used to analyze the homogeneity of variance. Tukey's HSD post hoc test $(\alpha=0.05)$ was used when significant differences between treatment mean occurred. When the assumption of sphericity was violated, Greenhouse and Geisser corrected statistics were used for degrees of freedom and $\mathrm{P}$ values.

Species richness was estimated from the abundance data using Chao 1 estimator. Sampling completeness for each land use was assessed by calculating the number of observed species as a percentage of this estimate. Since sample sizes were different, individual-based rarefaction analyses were used to compare the number of species between land-use types. To statistically check for differences between communities present among land uses, an analysis of similarity (ANOSIM) with Bonferroni correction was used. Differences in aquatic insect assemblages between land uses of headwater streams were visualized using nonmetric multidimensional scaling (NMDS). Similarity percentage (SIMPER) analysis was undertaken to identify those taxa which contributed most to statistical difference in aquatic insect assemblage composition between land uses. Prior to statistical analysis, species-abundance data was Hellinger transformed and all the values for the environmental variables were standardized. ANOSIM, NMDS, and SIMPER were conducted using the Bray-Curtis dissimilarity measure and performed in PAST 3.10 program (Hammer et al. 2001).

\section{RESULTS AND DISCUSSION}

\section{Environmental variables}

A summary of environmental stream variables of different land-use types is presented in Table 2. ANOVA showed significant differences of water temperature $\left(\mathrm{F}_{2,7}=\right.$ 72.55; $\mathrm{P}<0.001), \mathrm{pH}\left(\mathrm{F}_{2,7}=5.39 ; \mathrm{P}=0.038\right)$, and barely significant stream width $\left(\mathrm{F}_{2,7}=4.53 ; \mathrm{P}=0.055\right)$. Meanwhile, the lowest water temperature $\left(18.48{ }^{\circ} \mathrm{C}\right)$ was in the forest streams and the highest $\left(21.68{ }^{\circ} \mathrm{C}\right)$ in village streams (Table 2). The lower water temperature in the forest streams may be due to tree canopy shading. The $\mathrm{pH}$ was neutral and ranged from 6.79 in village to 7.60 in plantation streams. The width of streams located in the village was wider than those in forest and plantation areas. The highest dissolved oxygen was detected in forest streams $(7.30 \mathrm{~m} / \mathrm{l})$ and the lowest in plantation and village streams. Furthermore, the lowest turbidity was in forest streams (8.06 NTU) and the highest was in village streams (16.36 NTU). The current velocity ranged from $2.60 \mathrm{~m} / \mathrm{s}$ in forest streams to $3.12 \mathrm{~m} / \mathrm{s}$ in village streams. However, there were no significant differences of dissolved oxygen $\left(\mathrm{F}_{2,7}=0.37\right.$; $\mathrm{P}=0.70)$, turbidity $\left(\mathrm{F}_{2,7}=1.63 ; \mathrm{P}=0.26\right)$, and current velocity $\left(\mathrm{F}_{2,7}=2.12 ; \mathrm{P}=0.19\right)$.

PCA results (Table 2 column 5 and 6, Figure 2) showed that the first axis explained about $28.53 \%$ of the environmental variables variability, while the second axis explained 23.54\%. Furthermore, the first PCA axis separated most of the plantation streams from the forest and village streams, while the second axis separated forest and most of the plantation streams from the village streams. Those in forested areas were associated with high DO, low water temperature, and low turbidity. Also, those in tea 
plantations were associated with high $\mathrm{pH}$, low turbidity, and narrow in size. Conversely, streams in village areas were characterized by wider in size, high temperature, and high turbidity. In general, this ordination expresses a gradient of human impact and land uses in headwater streams of Ciliwung River watershed. Colzani et al. (2013) reported that streams located inside protected areas are characterized by high values of forest cover and high levels of dissolved oxygen, while those located in impacted areas, such as tea plantations and villages, are characterized by high water temperatures due to erosion.

\section{Aquatic insect fauna}

A total of 26531 specimens, mostly immatures, were examined during the study and represented 75 species/ morphospecies, 55 genera, 46 families, and 10 orders (Table 3). Trichoptera was the most common order with
13606 specimens (51.28\%), followed by Diptera with 8092 specimens (30.5\%). Other insects commonly collected were Ephemeroptera with 1995 specimens (7.52\%) and Plecoptera with 1647 specimens (6.25\%). Furthermore, the six other orders (Coleoptera, Collembola, Hemiptera, Lepidoptera, Megaloptera, and Odonata) represented less than 5\%. Altogether the EPT (Ephemeroptera, Plecoptera, Trichoptera) represented $65.05 \%$. The presence of EPTs indicated a preserved habitat integrity, since these invertebrates are sensitive to human disturbance and work as a proxy for invertebrate diversity and environmental quality (Bae and Park 2017; Andrade et al. 2020). In addition, the occurrence of diverse EPT larval communities is associated with low-polluted and well-oxygenated streams (Brasil et al. 2017).

Table 2. Environmental variables measured in streams classified by land-use types in Ciliwung River watershed, West Java, Indonesia. PCA loadings indicate the importance of each variable for axis 1 and 2

\begin{tabular}{|c|c|c|c|c|c|}
\hline \multirow{2}{*}{ Variables } & \multicolumn{3}{|c|}{ Land use } & \multicolumn{2}{|c|}{ PCA loadings } \\
\hline & Forest & Tea Plantation & Village & Axis 1 & Axis 2 \\
\hline Water temperature $\left({ }^{\circ} \mathrm{C}\right)$ & $18.48 \pm 0.17 \mathrm{a}^{*}$ & $20.43 \pm 0.25 b$ & $21.68 \pm 0.15 c$ & 0.6634 & -0.2767 \\
\hline Water $\mathrm{pH}$ & $7.15 \pm 0.22 \mathrm{ab}$ & $7.60 \pm 0.09 b$ & $6.79 \pm 0.04 \mathrm{a}$ & -0.0527 & -0.6580 \\
\hline Dissolved oxygen $(\mathrm{mg} / \mathrm{l})$ & $7.30 \pm 0.13 \mathrm{a}$ & $6.94 \pm 0.16 \mathrm{a}$ & $6.94 \pm 0.14 \mathrm{a}$ & -0.3354 & 0.4574 \\
\hline Turbidity (NTU) & $8.06 \pm 2.01 \mathrm{a}$ & $12.49 \pm 5.55 \mathrm{a}$ & $16.36 \pm 2.00 \mathrm{a}$ & 0.4421 & 0.1902 \\
\hline Current velocity $(\mathrm{m} / \mathrm{s})$ & $2.60 \pm 0.42 \mathrm{a}$ & $2.96 \pm 0.11 \mathrm{a}$ & $3.12 \pm 0.67 \mathrm{a}$ & 0.2303 & -0.0044 \\
\hline Width (m) & $1.70 \pm 0.31 \mathrm{ab}$ & $1.43 \pm 0.09 b$ & $2.47 \pm 0.17 \mathrm{a}$ & 0.4429 & 0.4951 \\
\hline
\end{tabular}

Note: *Different alphabets within the same rows are significantly different at $\mathrm{P} \leq 0.05$

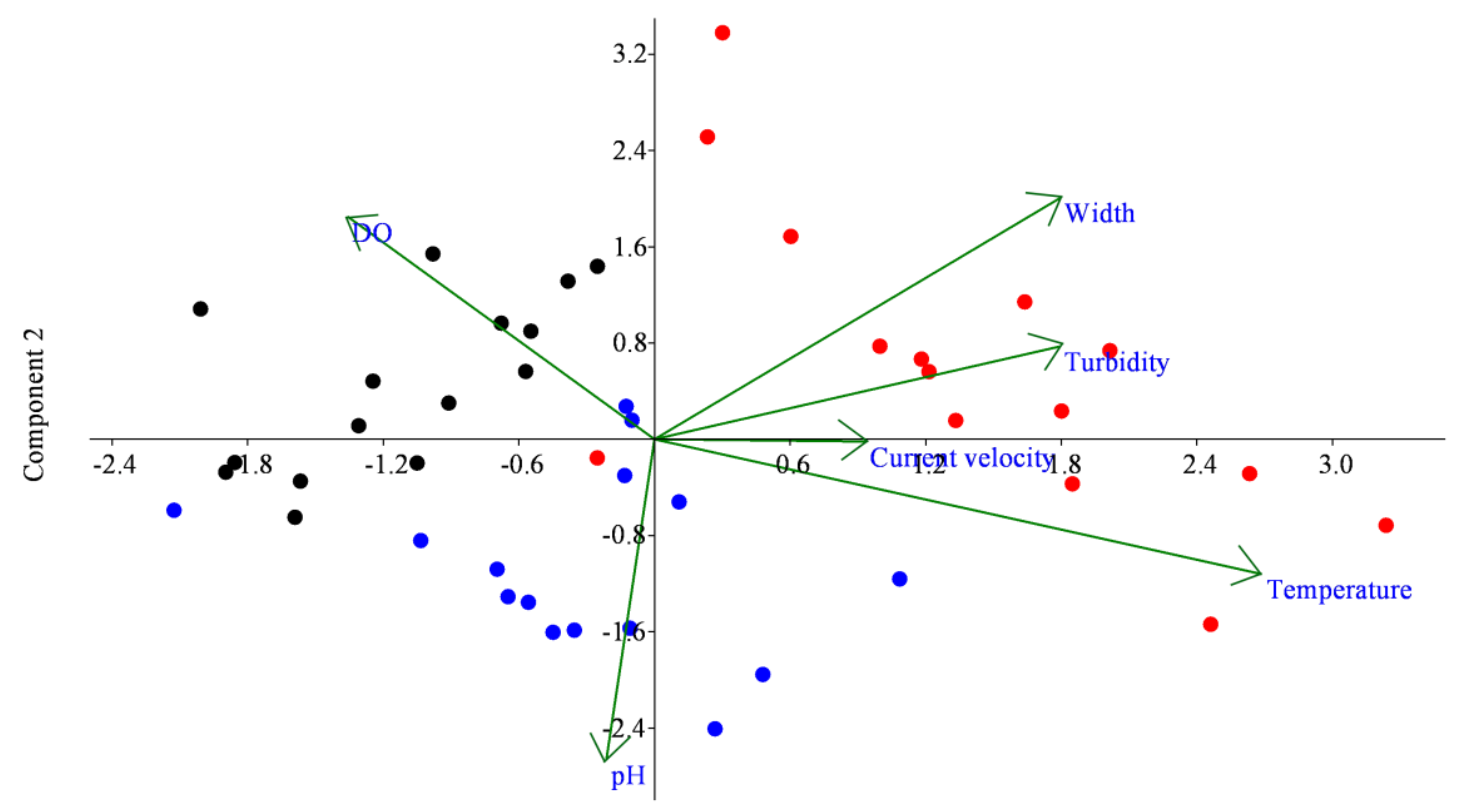

Component 1

Figure 2. Principal component analysis (PCA) of the headwater streams classified by land-use types in Ciliwung River watershed, West Java, Indonesia. Dots represent sampling streams. Note: $\bullet$ : forest, $\bullet$ : plantation, $\bullet$ : village streams 
Table 3. Abundance of aquatic insects collected from headwater streams of the Ciliwung River watershed, West Java, Indonesia

\begin{tabular}{|c|c|c|c|c|c|c|c|}
\hline \multirow{2}{*}{ Order } & \multirow{2}{*}{ Family } & \multirow{2}{*}{ Species } & \multirow{2}{*}{ FFG $^{*}$} & \multicolumn{3}{|c|}{ Land use } & \multirow{2}{*}{ Total } \\
\hline & & & & Forest & Tea plantation & Village & \\
\hline \multirow[t]{18}{*}{ Coleoptera } & Dytiscidae & Dytiscinae sp.1 & $\mathrm{P}$ & 100 & 1 & 16 & 117 \\
\hline & & Dytiscinae sp. 2 & $\mathrm{P}$ & 10 & 0 & 0 & 10 \\
\hline & & Dytiscinae sp. 3 & $\mathrm{P}$ & 2 & 0 & 0 & 2 \\
\hline & & Laccophilus sp. & $\mathrm{P}$ & 1 & 0 & 0 & 1 \\
\hline & Elmidae & Grouvellinus sp. & $\mathrm{SC}$ & 14 & 11 & 25 & 50 \\
\hline & & Stelnemis sp. & $\mathrm{SC}$ & 19 & 21 & 31 & 71 \\
\hline & Gyrinidae & Dineutus sp. & $\mathrm{P}$ & 117 & 8 & 19 & 144 \\
\hline & & Orectochilus sp. & $\mathrm{P}$ & 2 & 0 & 0 & 2 \\
\hline & Hydrophilidae & Amphiops mirabilis & GC & 1 & 0 & 0 & 1 \\
\hline & & Berosus sp. & GC & 7 & 0 & 5 & 12 \\
\hline & & Helochares sp. & GC & 2 & 0 & 0 & 2 \\
\hline & & Hydrophilidae sp. & GC & 4 & 0 & 1 & 5 \\
\hline & Lampyridae & Luciola sp.1 & $\mathrm{P}$ & 9 & 0 & 2 & 11 \\
\hline & & Luciola sp.2 & $\mathrm{P}$ & 12 & 1 & 3 & 16 \\
\hline & Psephenidae & Eubrianax sp. & $\mathrm{SC}$ & 1 & 0 & 0 & 1 \\
\hline & & Psephenus sp. & $\mathrm{SC}$ & 3 & 0 & 0 & 3 \\
\hline & Scirtidae & Scirtidae sp. 1 & $\mathrm{SH}$ & 68 & 0 & 6 & 74 \\
\hline & & Scirtidae sp.2 & $\mathrm{SH}$ & 5 & 0 & 0 & 5 \\
\hline \multirow[t]{2}{*}{ Collembola } & Isotomidae & Isotomidae sp.1 & $\mathrm{SH}$ & 0 & 0 & 1 & 1 \\
\hline & & Isotomidae sp.2 & SH & 1 & 2 & 0 & 3 \\
\hline \multirow[t]{17}{*}{ Diptera } & Atherichidae & Atrichops morimotoi & $\mathrm{P}$ & 33 & 0 & 2 & 35 \\
\hline & Ceratopogonidae & Atrichopogon fusculus & GC & 1 & 0 & 0 & 1 \\
\hline & & Bezzia sp. & $\mathrm{P}$ & 20 & 1 & 1 & 22 \\
\hline & Chironomidae & Chironomus sp. & GC & 631 & 285 & 270 & 1186 \\
\hline & & Polypedilum sp.1 & GC & 16 & 9 & 55 & 80 \\
\hline & & Polypedilum sp.2 & GC & 4 & 2 & 26 & 32 \\
\hline & & Procladius sp. & $\mathrm{P}$ & 105 & 76 & 150 & 331 \\
\hline & Empididae & Hilara sp. & $\mathrm{P}$ & 1 & 0 & 0 & 1 \\
\hline & Ephydridae & Ephydridae sp. & GC & 1 & 1 & 1 & 3 \\
\hline & Sciomyzidae & Pherbellia griseola & $\mathrm{P}$ & 1 & 0 & 0 & 1 \\
\hline & Simuliidae & Simulium sp. & $\mathrm{FC}$ & 2045 & 172 & 1085 & 3302 \\
\hline & Stratiomyidae & Oxycera sp. & $\mathrm{SC}$ & 1 & 0 & 0 & 1 \\
\hline & Tabanidae & Tabanidae sp. & $\mathrm{P}$ & 1 & 0 & 0 & 1 \\
\hline & Thaumalidae & Thaumalidae sp. & $\mathrm{SC}$ & 7 & 8 & 15 & 30 \\
\hline & Tipuliidae & Antocha sp. & GC & 9 & 114 & 476 & 599 \\
\hline & & Hexatoma sp. & $\mathrm{P}$ & 155 & 46 & 26 & 227 \\
\hline & & Tipula sp. & $\mathrm{SH}$ & 1111 & 800 & 329 & 2240 \\
\hline \multirow[t]{8}{*}{ Ephemeroptera } & Baetidae & Acentrella sp. & GC & 109 & 554 & 178 & 841 \\
\hline & & Baetis sp.1 & GC & 1 & 6 & 38 & 45 \\
\hline & & Baetis sp.2 & GC & 26 & 34 & 119 & 179 \\
\hline & & Baetis sp.3 & GC & 61 & 1 & 46 & 108 \\
\hline & Caenidae & Caenis sp. & GC & 2 & 7 & 1 & 10 \\
\hline & Heptageniidae & Thalerosphyrus sp. & GC & 19 & 0 & 1 & 20 \\
\hline & Isonychiidae & Isonychia sp. & $\mathrm{FC}$ & 159 & 267 & 357 & 783 \\
\hline & Leptophlebiidae & Leptophlebiidae sp. & GC & 5 & 0 & 4 & 9 \\
\hline \multirow[t]{8}{*}{ Hemiptera } & Gerridae & Metrocoris nigrofasciatus & $\mathrm{P}$ & 183 & 28 & 6 & 217 \\
\hline & Hebridae & Merragata sp. & $\mathrm{P}$ & 1 & 0 & 0 & 1 \\
\hline & Mesoveliidae & Mesovelia sp. & $\mathrm{P}$ & 0 & 1 & 0 & 1 \\
\hline & Micronectidae & Micronecta siva & $\mathrm{SC}$ & 1 & 0 & 0 & 1 \\
\hline & Naucoridae & Laccocoris sp. & $\mathrm{P}$ & 31 & 2 & 0 & 33 \\
\hline & Nepidae & Cercotmetus sp. & $\mathrm{P}$ & 4 & 0 & 0 & 4 \\
\hline & & Ranatra sp. & $\mathrm{P}$ & 2 & 0 & 0 & 2 \\
\hline & Veliidae & Rhagovelia sp. & $\mathrm{P}$ & 3 & 0 & 0 & 3 \\
\hline \multirow[t]{3}{*}{ Lepidoptera } & Crambidae & Elophila sp. & SH & 4 & 2 & 3 & 9 \\
\hline & & Eoophyla sp. & $\mathrm{SH}$ & 1 & 6 & 26 & 33 \\
\hline & & Potamomusa sp. & $\mathrm{SH}$ & 0 & 0 & 2 & 2 \\
\hline Megaloptera & Corydalidae & Protohermes sp. & $\mathrm{P}$ & 220 & 6 & 1 & 227 \\
\hline \multirow[t]{4}{*}{ Odonata } & Euphaeidae & Euphaea variegata & $\mathrm{P}$ & 14 & 0 & 2 & 16 \\
\hline & Libellulidae & Libellulidae sp. & $\mathrm{P}$ & 1 & 2 & 4 & 7 \\
\hline & & Orthetrum sp. & $\mathrm{P}$ & 16 & 18 & 52 & 86 \\
\hline & Macromiidae & Macromia sp. & $\mathrm{P}$ & 16 & 2 & 0 & 18 \\
\hline
\end{tabular}




\begin{tabular}{|c|c|c|c|c|c|c|c|}
\hline \multirow[t]{3}{*}{ Plecoptera } & Nemouridae & Nemoura sp. & SH & 1137 & 17 & 461 & 1615 \\
\hline & Perlidae & Neoperla sp.1 & $\mathrm{P}$ & 12 & 1 & 0 & 13 \\
\hline & & Neoperla sp.2 & $\mathrm{P}$ & 18 & 0 & 1 & 19 \\
\hline \multirow[t]{11}{*}{ Trichoptera } & Calamoceratidae & Anisocentropus sp. & $\mathrm{SH}$ & 1 & 0 & 0 & 1 \\
\hline & & Heteroplectron sp. & $\mathrm{SH}$ & 1 & 125 & 2 & 128 \\
\hline & Hydropsychidae & Cheumatopsyche sp. & FC & 517 & 1680 & 2761 & 4958 \\
\hline & & Hydropsyche sp. & FC & 663 & 1498 & 2063 & 4224 \\
\hline & & Diplectrona sp. & FC & 435 & 1291 & 1973 & 3699 \\
\hline & Hydroptilidae & Hydroptila sp. & $\mathrm{AP}$ & 18 & 0 & 2 & 20 \\
\hline & Lepidostomatidae & Lepidostoma sp. & SH & 169 & 26 & 15 & 210 \\
\hline & Limnephilidae & Pseudostenophylax sp. & SH & 0 & 1 & 0 & 1 \\
\hline & Philopotamidae & Chimarra sp. & $\mathrm{FC}$ & 65 & 2 & 25 & 92 \\
\hline & Polycentropodidae & Polycentropus sp. & $\mathrm{P}$ & 3 & 0 & 0 & 3 \\
\hline & Rhyacophilidae & Rhyacophila sp. & $\mathrm{P}$ & 164 & 12 & 94 & 270 \\
\hline
\end{tabular}

Note: *FC: Filtering-Collectors; GC: Gathering-Collectors; P: Predators; SC: Scrapers; SH: Shredders; AP: Algae Piercers

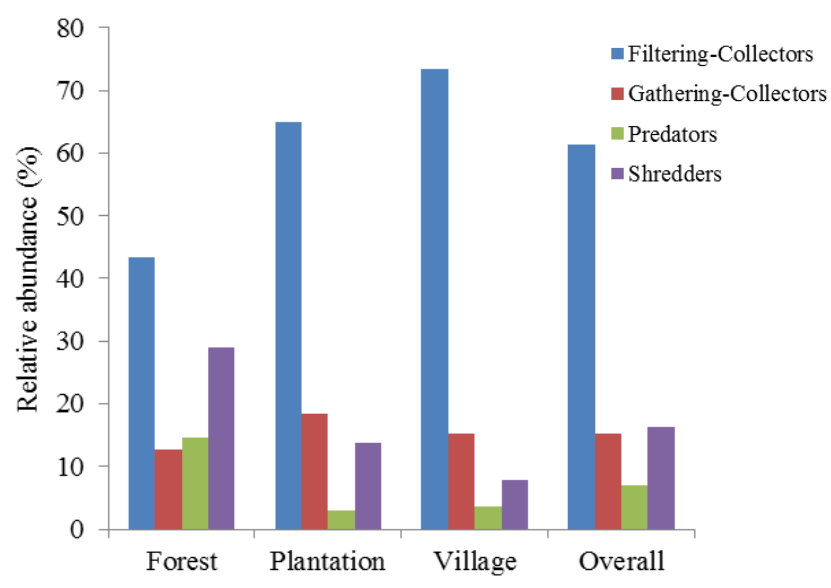

Figure 3. Relative abundance of aquatic insects among functional feeding groups classified by land-use types in Ciliwung River watershed, West Java, Indonesia. Scrapers and piercers represented $<0.25 \%$ of the insects sampled and are not shown

The order Diptera was represented by 17 taxa in 11 families, being the most abundant of Simuliidae, Tipulidae, and Chironomidae. A total of 3302 Simulium sp larvae were collected, and $61.9 \%$ was from forest streams. Hadi et al. (2019) who studied blackflies in headwater streams of Ciliwung River found 11 species with the most abundant was Simulium argyrocinctum De Meijere. Simuliid fauna of Indonesia has been thoroughly studied in recent years by Takaoka (Takaoka et al. 2017). Larvae of Simuliidae prefer running water habitats that contain high levels of dissolved oxygen, such as streams and waterfalls (Adler and Courtney 2019). The second most abundant dipteran were craneflies, and a total of 2240 Tipula sp. larvae were collected from all streams, with $85.3 \%$ from forest and plantation streams. Larvae were generally found in leaf packs at the bottom of the streams. Rasdi et al. (2012) reported Tipulidae as the second most abundant family in upper streams in Malaysia. The third most abundant dipteran was Chironomus sp. (Chironomidae), and a total of 1186 Chironomus sp. were collected, with $53.2 \%$ in forest streams. Most species of Chironomus have generalist and opportunistic feeding habits, using plant material and associated micro-organisms as a food source (Naser and
Roy 2012). Therefore, their distribution and abundance are strongly influenced by leaf litter features (Silveira et al. 2015). Chironomidae commonly posses the dominant status at the expense of other more sensitive groups, such as mayflies, stoneflies, and caddisflies (Li et al. 2010).

Ephemeroptera was represented by eight taxa in five families. Acentrella sp. (Baetidae) was the most numerous taxa followed by Isonychia sp. (Isonychiidae). Two species collected from West Java were Acentrella vera (Kluge et al. 2013) and Isonychia grandis (Vasanth et al. 2019). According to Kluge et al. (2013), the naiads of A. vera inhabit very diverse running waters, from clean and cool, to strongly polluted and warm, including Ciliwung River in the Bogor Botanical Garden.

The order Plecoptera was represented by three taxa in two families, and Nemoura sp. (Neumoridae) was the most abundant species. A total of 1616 naiads of Nemoura sp. were collected from all streams, with $70.4 \%$ from forest streams. Plecoptera prefers cool, natural, and clean streams with high dissolved oxygen concentration. Also, stoneflies are among the aquatic insects with higher sensitivity to pollution (DeWalt and Ower 2019).

The order Trichoptera was represented by 11 taxa in eight families. Malicky et al. (2014) recorded 146 species of caddisflies in Java, with 12 being collected from Cipanas (close to our research sites). It was found that Cheumatopsyche sp., Hydropsyche sp. and Diplectrona sp. (Hydropsychidae) were the most numerous, especially in plantation and village streams. In addition, Jung et al. (2008) reported that these three taxa were found abundantly in riffle areas of the middle stream reach in Vietnam.

\section{FFG composition}

The composition of functional feeding groups of aquatic insects varied among land-use types. Overall, the most abundant group was collectors $(61.34 \%$ were filtering-collectors and $15.32 \%$ were gathering-collectors), with lower abundance of shredders $(16.29 \%)$ and predators $(6.94 \%)$ (Figure 3). Filtering- and gathering-collectors feed on fine particulate organic matter (FPOM, particles < 1 $\mathrm{mm}$ ) (Cummins 2018). The filtering-collectors composed of $43.30 \%$ in forest streams, $64.96 \%$ in plantation streams, and $73.34 \%$ in village streams. The filtering-collectors in headwater streams of Ciliwung River watershed composed 
mainly of Simulium sp. larvae and hydropsychids (Cheumatopsyche sp., Hydropsyche sp., Diplectrona sp.), and include mayfly genus Isonychia (Cummins 2016). Simuliid larvae were relatively abundant, particularly in the upper reaches, and remove FPOM from the passing water column using filtering fans (Jung et al. 2008). The Hydropsychidae inhabit surface of large and stable substrates (i.e. bedrock, boulders, and cobbles), and construct tent-like nets to capture food particles brought by water current (Cummins 2018). Filtering-collectors commonly inhabit fast-flowing water that allow them efficiently obtain organic matters (Morse et al. 2019). The gatheringcollectors browse FPOM from interstices in the bottom sediments (Cummins 2018). The gathering-collectors are mainly composed of Chironomus sp. larvae and ephemeropteran such as Acentrella sp. and other baetids.

The shredders consume leaf litter or other coarse particulate organic matter (CPOM, particles $>1 \mathrm{~mm})$. The proportion of shredders was higher in the forest stream $(29.04 \%)$ than in plantation $(13.70 \%)$ and village streams (7.84\%) (Figure 3). In this study, the shredders composed mainly of Nemouridae and Tipulidae. The higher percentage of shredders in the forest streams could be due to CPOM accumulation (Encalada et al. 2010). Shredders were also reported to be somewhat more abundant in upper stream sites in various Asian countries such as Korea (Hoang and Bae 2006), Vietnam (Jung et al. 2008), and Malaysia (Shafie et al. 2017).

Predators consume living animal tissue as the dominant food type and have specific adaptations to capture prey (Cummins 2018; Suriyawong et al. 2018). Predators were relatively higher in forest streams $(14.61 \%)$ than in plantation $(2.87 \%)$ and village streams $(3.52 \%)$ (Figure 3$)$. In this study, predators composed mainly of Dytiscidae, Dineutus sp. (Gyrinidae), Procladius sp. (Chironomidae), Hexatoma sp. (Tipulidae), Metrocoris nigrofasciatus (Gerridae), Protohermes sp. (Corydalidae), and Rhyacophila sp. (Rhyacophilidae).

Scrapers were scarce in all studied headwater streams, and ranged from $0.11 \%$ in plantation to $0.15 \%$ in forest streams, and composed mainly of Thaumalidae larvae (Diptera). Scrapers use their adapted mouthparts to graze on periphyton, such as attached algae (Cummins 2018). The lower percentage of scrapers in these headwater streams is likely an indicator of the scarcity of algal growth on substrates available in the streams. According to Hoang and Bae (2006), the distributions of FFGs are closely related to food resources available along the stream channel.

\section{Spatial and temporal abundance}

Results of the repeated-measures ANOVA showed that the mean abundance of Diptera, Ephemeroptera, Plecoptera, and Trichoptera differed significantly between land-use types (Table 4). Meanwhile, insects that belong to order Diptera were more abundant in forest streams $(82.90$ \pm 8.36 per $\left.\mathrm{m}^{2}\right)$ compared to those in village $(48.72 \pm 6.71$ per $\left.\mathrm{m}^{2}\right)$ and plantation streams $\left(30.28 \pm 2.62\right.$ per $\left.\mathrm{m}^{2}\right)$. The high abundance of Diptera was due to the high number of Simulium sp. and Tipula sp. larvae. Immature black flies prefer running water habitats that contains high dissolved oxygen levels, such as streams, and waterfalls. Similarly, insects that belong to order Plecoptera were more abundant in forest streams $\left(23.34 \pm 3.88\right.$ per $\left.\mathrm{m}^{2}\right)$ than in village $(9.24$ \pm 3.45 per $\left.\mathrm{m}^{2}\right)$ and plantation streams $\left(0.90 \pm 0.36\right.$ per $\left.\mathrm{m}^{2}\right)$. Meanwhile, Plecoptera that relies heavily on high oxygenated water is expected to be higher in forest streams. However, insects of the order Ephemeroptera were more abundant in plantation $\left(17.38 \pm 2.93\right.$ per $\left.\mathrm{m}^{2}\right)$ and village streams $\left(14.88 \pm 3.52\right.$ per $\left.\mathrm{m}^{2}\right)$ than in forest streams $(7.64 \pm$ 1.10 per $\mathrm{m}^{2}$ ). Insects of the order Trichoptera were more abundant in village streams $\left(138.70 \pm 19.02\right.$ per $\left.\mathrm{m}^{2}\right)$ than in plantation $\left(92.70 \pm 15.56\right.$ per $\left.\mathrm{m}^{2}\right)$ and forest streams $(40.72$ \pm 6.71 per $\mathrm{m}^{2}$ ) (Table 4). Although generally classified as intolerant, populations of some caddisfly species may actually increase with increased organic pollution. This phenomenon is especially pronounced among caddisflies in the filtering-collector functional group, as these organisms may utilize added fine organic particles as a food resource. In addition, disturbances that add such organic material to aquatic ecosystem may promote an increase in the abundance of some filtering-collector species (Houghton 2004), as also reported for Ciliwung River (Sudarso et al. 2013).

Table 4. Results from repeated-measures ANOVA on abundance of aquatic insects in headwater streams of Ciliwung River watershed, West Java, Indonesia

\begin{tabular}{|c|c|c|c|c|}
\hline Insect order & Item & $\mathbf{F}$ & $\mathbf{P}$ & Pairwise comparison* \\
\hline \multirow[t]{3}{*}{ Diptera } & Land use & 17.033 & $<0.001$ & Fores $^{\mathrm{a}}>$ Village $^{\mathrm{b}}>$ Plantation $^{\mathrm{b}}$ \\
\hline & Month & 20.910 & $<0.001$ & June $^{\mathrm{a}}>$ December $^{\mathrm{b}}>$ October $^{\mathrm{b}}>$ August $^{\mathrm{a}}>$ April $^{\mathrm{c}}$ \\
\hline & Land use * Month & 11.532 & $<0.001$ & \\
\hline \multirow[t]{3}{*}{ Ephemeroptera } & Land use & 8.712 & 0.001 & Plantation $^{\mathrm{a}}>$ Village $^{\mathrm{a}}>$ Forest $^{\mathrm{b}}$ \\
\hline & Month & 25.557 & $<0.001$ & June $^{\mathrm{a}}>$ April $^{\mathrm{b}}>$ October $^{\mathrm{b}}>$ December $^{\mathrm{c}}>$ August $^{\mathrm{c}}$ \\
\hline & Land use * Month & 18.620 & $<0.001$ & \\
\hline \multirow[t]{3}{*}{ Plecoptera } & Land use & 50.953 & $<0.001$ & Forest $^{\mathrm{a}}>$ Village $^{\mathrm{b}}>$ Plantation $^{\mathrm{b}}$ \\
\hline & Month & 31.633 & $<0.001$ & December $^{\mathrm{a}}>$ October $^{\mathrm{b}}>$ June $^{\mathrm{c}}>$ April $^{\mathrm{c}}>$ August $^{\mathrm{c}}$ \\
\hline & Land use * Month & 12.277 & $<0.001$ & \\
\hline \multirow[t]{3}{*}{ Trichoptera } & Land use & 34.914 & $<0.001$ & Village $^{\mathrm{a}}>$ Plantation $^{\mathrm{b}}>$ Forest $^{\mathrm{b}}$ \\
\hline & Month & 55.063 & $<0.001$ & June $^{\mathrm{a}}>$ April $^{\mathrm{a}}>$ August $^{\mathrm{b}}>$ October $^{\mathrm{b}}>$ December $^{\mathrm{b}}$ \\
\hline & Land use * Month & 32.729 & $<0.001$ & \\
\hline
\end{tabular}

Note: * In pairwise comparisons, habitat and month followed by different letters are significantly different by Tukey's HSD test (p<0.05) 


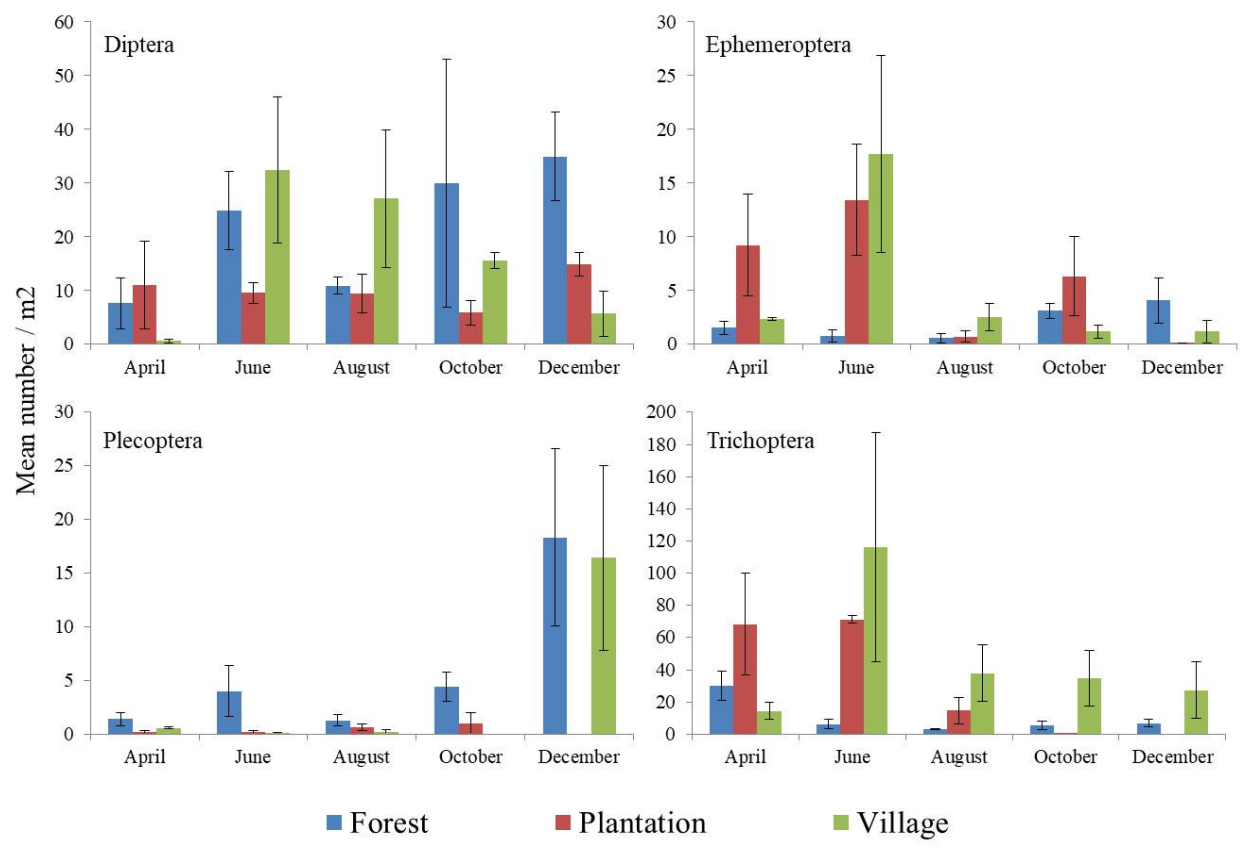

Figure 4. Abundance $(x \pm S E)$ of major aquatic insect orders in the headwater streams of the Ciliwung River watershed, West Java, Indonesia

All the taxa showed significant temporal differences (Table 4). Also, significant habitat $\mathrm{x}$ month interaction terms were observed for all taxa, suggesting that their mean abundances varied differently over time between streams (Figure 4). The highest abundance of Diptera (74.57 \pm 6.81 per $\left.\mathrm{m}^{2}\right)$, Ephemeroptera $\left(32.00 \pm 5.68\right.$ per $\left.\mathrm{m}^{2}\right)$, and Trichoptera (196.03 \pm 29.49 per $\left.\mathrm{m}^{2}\right)$ occurred in June (dry period), while for Plecoptera $\left(48.79 \pm 7.71\right.$ per $\left.^{2}\right)$ was in December (rainy period). In general, abundance increase during dry period and decrease during rainy period. In fact, food availability and shelter are more available in the dry season, and litter production is increased during the dry season, through increased leaf-fall rates from the riparian vegetation (Wantzen et al. 2008). It is probable that in the wet period, such material is transported downstream by the current. Also, the environments are more stable in the dry season, allowing species colonization and establishment. However, in the rainy season, only species with morphological adaptations that allow them to resist the water force and constant disturbances caused by rain can survive (Santana et al. 2015). The high organisms abundance during period of low flow may also be related to the reduced availability of habitat area and the consequent increase in individual aggregation. Even when there is no reduction in fauna due to increased organisms removal in the rainy season, the fact that the available area is increased in the dry season would be sufficient to increase density (Dudgeon 1997).

Several works have reported a marked reduction in the abundance of aquatic insects during rainfall period, which in general agrees with the results of this study. Also, the high rate of rainfall increases water debit and flow velocity. High current velocity can affect aquatic insect populations, and the large flow increase during rainy season might lead to the removal of benthic fauna through physical disturbance of the substrate (Righi-Cavallaro et al. 2010). However, it was found that the plecopterans were much more abundant in December (wet period). Hamid and Che Salmah (2011) also reported that more plecopteran was collected in the wet season. Rainfall events can promote an increase in the amount of allochthonous organic matter from terrestrial sources (Lisboa et al. 2015). Therefore, it was believed that Plecoptera are directly dependent on the amount of vegetal material in the environment, and they increase their abundance in the rainy season (Santana et al. 2015).

\section{Species richness and diversity}

Although the number of specimens collected from the village streams was higher, more species were found in the forest streams (Table 5). Estimation of species richness by Chao 1 showed that expected species richness for plantation and village streams were close to their observed values, with sampling completeness of $92.3 \%$ each. The estimate of species richness for forest streams was higher than the observed value by 23 species, or the sampling completeness was about $76 \%$. Comparing the individualbased rarefaction curves at the point which permits the comparison of the three land-use types (7000 individuals), forest streams accumulated 68 species, while plantation and village stream accumulated 42 and 44 species, respectively (Table 5; Figure 5). The differences between forest streams and the others are significant given the calculated 95\% confidence intervals, but there was no significant difference in the number of species found in plantation and village streams. In this study, the higher species richness in the forest streams was mainly due to a higher number of insect species in the order Coleoptera and Hemiptera. 
Table 5. Observed and rarefied species richness as well as expected number of species according to the Chao 1 estimator in streams of three land-use types. Number of specimens and diversity index (Shannon-Wiener) are also included

\begin{tabular}{lccc}
\hline \multicolumn{1}{c}{ Parameter } & \multicolumn{3}{c}{ Land use } \\
\cline { 2 - 4 } & Forest & Tea plantation & Village \\
\hline No. of specimens & 8602 & 7147 & 10782 \\
Observed species richness & 71 & 42 & 48 \\
Estimated species & 93.66 & 45.50 & 52 \\
richness (Chao 1) & & & \\
S rar* (7,000) & 67.6 & 41.8 & 44.3 \\
Shannon-Wiener (H) & 2.68 & 2.19 & 2.27 \\
\hline
\end{tabular}

Note: *Number of species rarefied for 7000 individuals.

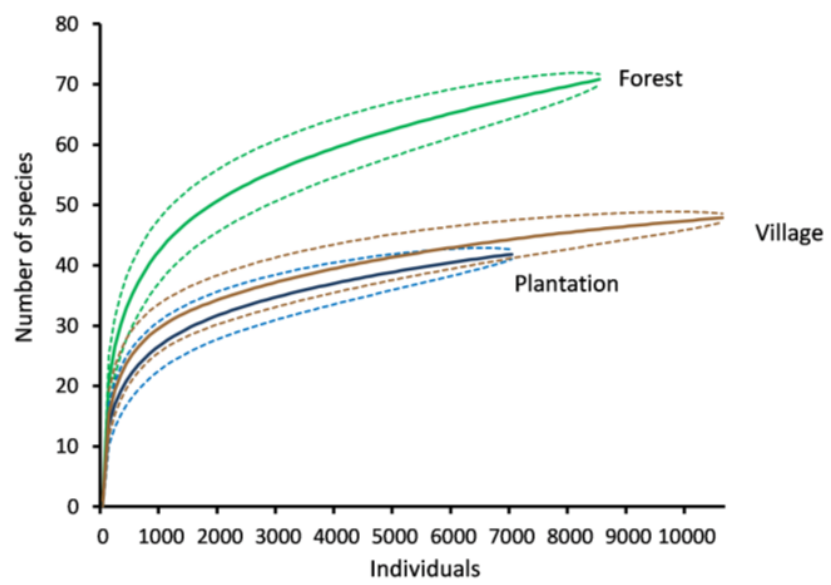

Figure 5. Individual-based rarefaction curves for aquatic insects inhabiting streams classified by land-use types. Solid lines are observed species richness data and dashed lines indicate 95\% confidence bounds. Curves are generated from 100 randomization

In addition to having a higher species richness, forest stream also showed higher species diversity (Table 5). Shannon-Wiener diversity index $(\mathrm{H})$ was significantly higher in forest streams compared to the tea plantation $(\mathrm{t}=25.91 ; \mathrm{df}=15716 ; \mathrm{P}<0.001)$ and village streams $(\mathrm{t}=4.86$; $\mathrm{df}=16099 ; \mathrm{P}<0.001)$. Vegetation along the forest stream banks reduce the autotrophic production because of shading and provides a large litter amount composed of leaves, stems, fruits, and seeds. Furthermore, the accumulation of allochthonous material in stream beds increases the spatial heterogeneity of the environment, enabling the coexistence of a rich variety of aquatic insects (Silveira et al. 2015). In forest headwater streams, the majority of energy inputs are detrital, therefore maintaining diverse riparian inputs of organic matter is important for detritivore productivity in forested headwater watersheds (Eckert et al. 2020; Eggert et al. 2020). In addition to providing continuous allochthonous food sources, the vegetation also serves as a shelter for adult insects to rest or mate (Che Salmah et al. 2013). Therefore, different land uses alter not only habitat conditions and water quality, but also the benthic invertebrate assemblages (Melo et al 2020).
Colzani et al. (2013) showed evidence of the harmful effects caused by landscape changes on biodiversity, which suggests that these effects also influence the functional organization of stream insect communities. Also, van Bierviliet et al. (2009) reported that species richness and aquatic insect diversity were lower in tea plantation streams than in forest streams in Tanzania. Similarly, taxonomic richness and diversity of aquatic insects were higher in the reference (forest) streams than in agricultural and urban streams as reported in Brazil (Hepp et al. 2010) and Malaysia (Shafie et al. 2017). Meanwhile, disturbance in riparian areas increases fine sediment loads into streams, damaging habitat, and altering the aquatic insect assemblages (Yoshimura 2012). Bere et al. (2016) reported that a decrease in riparian vegetation percentage in tropical streams can shift benthic macroinvertebrate assemblages from dominance by specialist forest taxa to simplified communities dominated by generalist taxa. In addition, siltation modifies the habitat structure of the streambed, decreases the aquatic system productivity, reduces epiphytic algal biomass indirectly affecting the grazing invertebrates that feed on these algae. Wang and Tau (2017) found that water quality was more important than land-use in structuring macroinvertebrate communities.

\section{Community similarity}

The ANOSIM comparisons of the aquatic insect assemblages showed a somewhat dissimilarity (Global $\mathrm{R}=0.217 ; \mathrm{P}<0.001)$ among streams based on the land use types. The pairwise ANOSIM showed a significant dissimilarity between forest and plantation streams ( $\mathrm{R}=0.331 ; \mathrm{P}<0.001)$, and between forest and village streams $(\mathrm{R}=0.319 ; \mathrm{P}<0.001)$. However, there was no significant dissimilarity of aquatic insect assemblages between plantation and village streams $(\mathrm{R}=0.083$; $\mathrm{P}=0.137)$. An R-value that approaches one indicates strongly distinct assemblages, while value close to zero indicates that the assemblages are barely separable (Gardener 2014). This low dissimilarity level was supported by the result of NMDS ordination (Figure 6) which showed a large degree of overlap on the aquatic insect assemblages among streams of the three land-use types. Also, the aquatic insect community from forest streams showed less variations between replicates compared to those from plantation and village streams. Earlier PCA analysis in this study suggested that the forest streams were more associated with lower water temperature and higher dissolved oxygen (DO). Conversely, plantation and village streams were more associated with higher water temperature and lower dissolved oxygen. dos Reis Oliveira et al. (2019) reported that streams receiving forest inputs (leaves and woody debris) sustained a relatively stable high oxygen regime and a diverse macroinvertebrate community. Furthermore, different land uses alter not only habitat conditions and water quality, but also the benthic invertebrate community structure (Melo et al. 2020). In a lotic ecosystem, especially streams, biological condition is strongly influenced by physicochemical water and habitat quality (Bio et al. 2011; Payakka and Prommi 2014). 


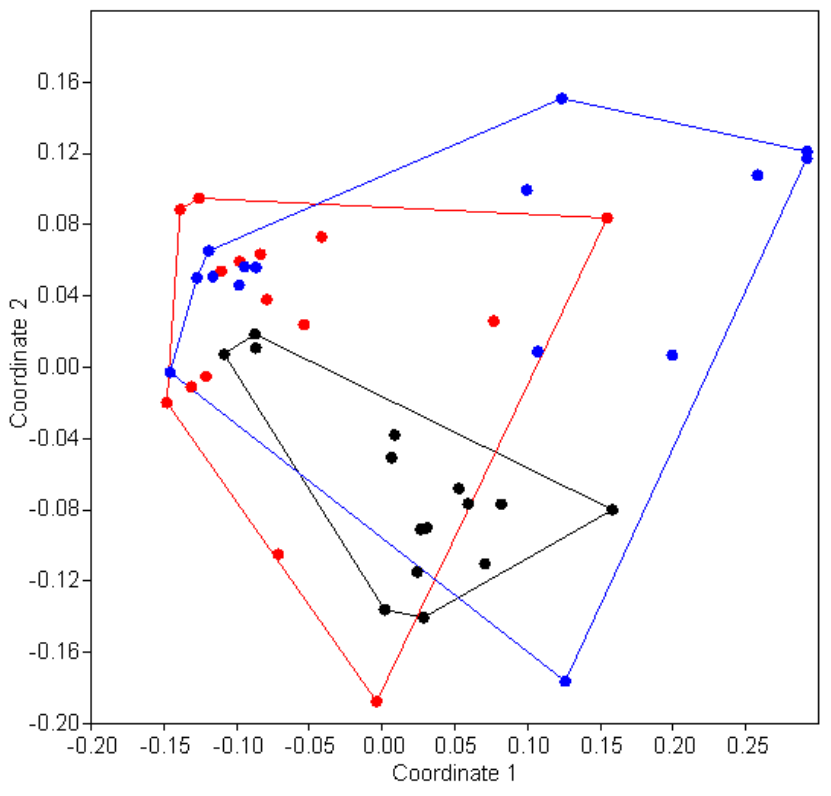

Figure 6. Non-metric multidimensional scaling (NMDS) of aquatic insect assemblages inhabiting headwater streams classified by land-use types (stress: 0.14 ). Dots represent samples $(\bullet$ : forest, $\bullet$ : plantation, $\bullet$ : village streams)

The top five aquatic insect taxa (identified by SIMPER analysis) driving the difference in community composition between forest and plantation streams were Tipula sp. (contributing $9.28 \%$ to the dissimilarity), Nemoura sp. $(7.37 \%)$ and Simulium sp. $(6.50 \%)$ which were recorded in higher abundance in forest streams, and Hydropsyche sp. (6.91\%) and Cheumatopsyche sp. (6.29\%) which were recorded a higher abundance in plantation streams. Also, higher abundance of Nemoura sp. (7.99\%), Simulium sp. (6.34\%) and Chironomus sp. (6.15\%) in forest streams, and Hydropsyche sp. (7.79\%) and Cheumatopsyche sp. (7.24\%) in village streams, were identified by SIMPER as the top five aquatic insect taxa driving the community dissimilarity between forest and village streams.

\section{Implication of the study for conservation}

The findings provide the first comprehensive investigation of aquatic insects in the headwater streams of the Ciliwung River watershed and offer implications for conservation. The fact that aquatic insect biodiversity was extremely high in headwater streams suggests that watershed preservation programs may be important to conserve freshwater biodiversity. Meanwhile, highland running-water biodiversity has gained growing interest around the world, because of their more pristine conditions and higher sensitivity to environmental changes compared to lowland rivers (Xu et al. 2018). Tropical freshwaters are among the most threatened ecosystems, experiencing biodiversity loss at alarming rates (Sundar et al. 2020). In addition, landscape alterations including deforestation, urbanization, and water withdrawal have been the main threats to lotic habitats (Santos and Stevenson 2011; do Amaral et al. 2015; Lundquist and Zhu 2019).
Headwater streams are the source for downstream environments and provide support for the stream network in terms of water quality, as well as resources such as organic matter. However, they are most likely to receive the least protection from land use, and probably require more conservation action (Richardson 2019). Also, headwater streams are among the most sensitive freshwater ecosystems, due to their intimate linkage with catchments (Richardson 2019). In particular, the aquatic biota of headwater streams is among the most imperiled species, as small streams are more sensitive to disturbance and anthropogenic impacts than larger ones (Santos and Stevenson 2011). Furthermore, a higher proportion of freshwater species are threatened with extinction than their terrestrial counterparts (Dudgeon 2010). Therefore, deterioration of aquatic biodiversity has become one of the main concerns in recent conservational and ecological studies in various parts of the world (Che Salmah et al. 2013; Braun et al. 2014; Edia et al. 2016; Hill et al. 2016; Principe et al. 2019).

Headwater streams of Ciliwung River watershed are currently experiencing significant anthropogenic disturbances that may affect ecosystem functioning (Sudarso et al. 2013). The finding showed that the streams surrounded by forested areas had higher biodiversity levels than those surrounded by tea plantations and villages. This change in aquatic insect community may be indicative of a change in ecosystem structure, functioning, and a resultant reduction in services by plantation and village stream ecosystems. Therefore, the results are relevant to support conservation and management plans in the basin, especially because Ciliwung River provides water for agriculture, industry, sanitation, and drinking water.

In conclusion, the headwater streams support a rich fauna of aquatic insects. Furthermore, species richness and diversity are higher in forest streams and reduced in those surrounded by tea plantations and villages. Overall, the results show the need for forest area preservation in the headwater streams of Ciliwung River watershed to protect freshwater biodiversity.

\section{ACKNOWLEDGEMENTS}

We are grateful to Prof. I Wayan Suana (University of Mataram, Indonesia), Dr. Akhmad Rizali (University of Brawijaya, Malang, Indonesia), and an anonymous reviewer for reading the manuscript and providing valuable comments. This work was supported by the research grant from the Ministry of Research, Technology and Higher Education, Indonesia through PMDSU scholarship program.

\section{REFERENCES}

Abell R, Vigerstol K, Higgins J, Kang S, Karres N, Lehner B, Sridhar A, Chapin E. 2019. Freshwater biodiversity conservation through source water protection: Quantifying the potential and addressing the challenges. Aquat Conserv 29 (7): 1022-1038. DOI: 10.1002/aqc.3091. 
Adler PH, Courtney GW. 2019. Ecological and societal services of aquatic Diptera. Insects 10 (3): 70. DOI: 10.3390/insects10030070.

Al-Shami SA, Che Salmah MR, Ahmad AH, Madrus MR. 2013. Biodiversity of stream insects in the Malaysian Peninsula: Spatial patterns and environmental constraints. Ecol Entomol 38 (3): 238249. DOI: 10.1111/een.12013.

Andrade ICP, Krolow TK, Boldrini R, Pelicice FM. 2020. Diversity of EPT (Ephemeroptera, Plecoptera, Trichoptera) along streams fragmented by waterfalls in the Brazilian Savanna. Neotrop Entomol 49: 203-212. DOI: 10.1007/s13744-019-00751-z.

Bae MJ, Park YS. 2017. Diversity and distribution of endemic stream insects in a nationwide scale, South Korea: Conservation perspectives. Water 9 (11): 833. DOI: 10.3390/w9110833.

Bere T, Chiyangwa G, Mwedzi T. 2016. Effects of land-use changes on benthic macroinvertebrate assemblages in the tropical Umfurudzi River, Zimbabwe. Afr J Aquat Sci 41 (3): 353-357.

Bio A, Vieira N, Costa, MJ, Valente A. 2011. Assessment of habitat and water quality of the Portuguese Febros River and one of its tributaries. Limnetica 30 (1): 103-116. DOI: 10.23818/limn.30.09.

Brasil LS, da Silva Giehl NF, Batista JD, de Resende BO, Cabette HSR 2017. Aquatic insects in organic and inorganic habitats in the streams on the Central Brazilian savanna. Rev Colomb Entomol 43 (2): 286291.

Braun BM, Pires MM, Kotzian CB, Spies MR. 2014. Diversity and ecological aspects of aquatic insect communities from montane streams in Southern Brazil. Acta Limnol Bras 26 (2): 186-198.

Bucker A, Sondermann M, Frede HG, Breuer L. 2010. The influence of land use on macroinvertebrate communities in montane tropical streams - A case study from Equador. Fund Appl Limnol 177 (4): 267-282.

Che Salmah MR, Al-Shami SA, Madrus MR, Ahmad AH. 2013. Local effects of forest fragmentation on diversity of aquatic insects in tropical forest streams: Implications for biological conservation. Aquat Ecol 47: 75-85. DOI: 10.1007/s10452-012-9426-8.

Cheng L, Yang CM, Andersen NM. 2001. Guide to the aquatic Heteroptera of Singapore and Peninsular Malaysia. I. Gerridae and Hermatobatidae. Raffles B Zool 49 (1): 129-148.

Clarke A, Nally RM, Bond N, Lake PS. 2008. Macroinvertebrate diversity in headwater streams: A review. Freshw Biol 53: 1707-1721. DOI 10.1111/j.1365-2427.2008.02041.x

Colzani E, Siqueira T, Suriano MT, Roque FO. 2013. Responses of aquatic insect functional diversity to landscape changes in Atlantic forest. Biotropica 45 (3): 343-350. DOI: 10.1111/btp.12022.

Cummins KW. 2016. Combining taxonomy and function in the study of stream macroinvertebrates. J Limnol 75 (s1): 235-241.

Cummins KW. 2018. Functional Analysis of Stream Macroinvertebrates. Limnology: Some New Aspects of Inland Water Ecology. IntechOpen, London.

DeWalt RE, Ower GD. 2019. Ecosystem services, global diversity, and role of stonefly species descriptions (Insecta: Plecoptera). Insects 10 (4): 99. DOI: 10.3390/insects10040099.

Dijkstra KDB, Monaghan MT, Pauls SU. 2014. Freshwater biodiversity and aquatic insect diversification. Ann Rev Entomol 59 (1): 143-163.

do Amaral PHM, da Silveira LS, Rosa BFJV, de Oliveira VC, da Gama Alves R. 2015. Influence of habitat and land use on the assemblages of Ephemeroptera, Plecoptera, and Trichoptera in Neotropical streams. J Insect Sci 15 (1): 1-7. DOI: 10.1093/jisesa/iev042.

dos Reis Oliveira PC, van der Geest HG, Kraak MHS, Verdonschot PFM. 2019. Land use affects lowland stream ecosystems through dissolved oxygen regimes. Sci Rep 9: 19685. DOI: 10.1038/s41598-019-56046

Dudgeon D. 1997. Life histories, secondary production, and microdistribution of hydropsychid caddisflies (Trichoptera) in a tropical forest stream. J Zool 243 (1): 191-210.

Dudgeon D. 2010. Prospects for sustaining freshwater biodiversity in the 21st century: Linking ecosystem structure and function. Curr Opin Environ Sustain 2 (5-6): 422-430. DOI: 10.1016/j.cosust.2010.09.001

Eckert RA, Halvorson HM, Kuehn KA, Lamp WO. 2020. Macroinvertebrate community patterns in relation to leaf-associated periphyton under contrasting light and nutrient conditions in headwater streams. Freshw Biol. DOI: 10.1111/fwb.13473.

Edia OE, Castella E, Konan MK, Gattolliat JL, Ouattara A. 2016. Diversity, distribution and habitat requirements of aquatic insect communities in tropical mountain streams (South-eastern Guinea, West Africa). Ann Limnol Intl J Lim 52: 285-300. DOI: $10.1051 / \mathrm{limn} / 2016016$
Eggert SL, Wallace JB, Meyer JL, Webster JR. 2020. Trophic basis of production of stream detritivores shifts with reduced forest inputs. Hydrobiologia 847: 3091-3101. DOI: 10.1007/s10750-020-04317-8.

Encalada AC, Calles J, Ferreira V, Canhoto CM, Graça MAS. 2010. Riparian land use and the relationship between the benthos and litter decomposition in tropical montane streams. Freshw Biol 55 (8): 1719. 1733. DOI: 10.1111/j.1365-2427.2010.02406.x.

Gardener M. 2014. Community Ecology: Analytical Methods Using R and Excel. Pelagic Publishing, Exeter, UK

Hadi UK, Soviana S, Rohmah IL. 2019. Diversity and ecology of black flies in tea plantation area of Puncak Bogor, Indonesia. Acta Trop 199: 104986. DOI: 10.1016/j.actatropica.2019.04.010.

Hamid SA, Che Salmah MR. 2011. Stoneflies (Insecta: Plecoptera) in Malaysian tropical rivers: Diversity and seasonality. J Entomol Nematol 3 (2): 030-036.

Hammer O, Harper DAT, Ryan PD. 2001. PAST: paleontological statistical software package for education and data analysis. Paleontol Electron 4 (1): 1-9.

Hepp LU, Milesi SV, Biasi C, Restello RM. 2010. Effects of agricultural and urban impacts on macroinvertebrate assemblages in streams (Rio Grande do Sul, Brazil). Zoologica 27 (1): 106-113.

Hepp LU, Restello RM, Milesi SV, Biasi C, Molozzi J. 2013. Distribution of aquatic insects in urban headwater streams. Acta Limnol Bras 25 (1): 1-9.

Hill MJ, Chadd RP, Morris N, Swaine JD, Wood PJ. 2016. Aquatic macroinvertebrate biodiversity associated with artificial agricultural ditches. Hydrobiologia 776: 249-260. DOI: 10.1007/s10750-0162757-z.

Hoang DH, Bae YJ. 2006. Aquatic insect diversity in a tropical Vietnamese stream in comparison with that in a temperate Korean stream. Limnology 7: 45-55.

Houghton DC. 2004. Utility of caddisflies (Insecta: Trichoptera) as indicators of habitat disturbance in Minnesota. J Freshw Ecol 19 (1): 97-108

Jung SW, Nguyen VV, Nguyen QH, Bae YJ. 2008. Aquatic insect faunas and communities of a mountain stream in Sapa Highland, northern Vietnam. Limnology 9 (3): 219-229.

Kluge NJ, Sivarakrishnan KG, Selvakumar C, Kubendran T. 2013. Notes about Acentrella (Liebebiella) vera (Muller-Libenau, 1982) (=Pseudocloeon difficilum Muller-Liebenau, 1982 syn. $\mathrm{N}=$ Platybaetis arunachalae Selvakumar, Sundar, and Sivaramakrishnan, 2012 syn. n.) (Ephemeroptera: Baetidae). Aquat Insect 35 (3-4): 6370 .

Koroiva R, Pepinelli M. 2019. Distribution and habitats of aquatic insects. In: Del-Claro K, Guillermo R (Eds). Aquatic Insects: Behavior and Ecology. Springer, Switzerland.

Li L, Zheng B, Liu L. 2010. Biomonitoring and bioindicators used for river ecosystems: Definition, approach and trends. Procedia Environ Sci 2: 1510-1524. DOI: 10.1016/j.proenv.2010.10.164.

Lisboa LK, Lemes-Silva AL, Siegloch AE, Goncalvez-Junior JF, Petrucio MM. 2015. Temporal dynamics of allochthonous coarse particulate organis matter in a subtropical Atlantic rainforest Brazilian stream. Mar Freshw Res 66 (8): 674-680.

Lundquist MJ, Zhu W. 2019. Aquatic insect diversity in streams across a rural-urban land-use discontinuum. Hydrobiologia 837: 15-30. DOI: 10.1007/s10750-019-3955-2

Malicky H, Ivanov VD, Melnitsky SI. 2014. Caddisflies (Trichoptera) from Lombok, Bali and Java (Indonesia), with a discussion of Wallace's line. Dtsch Entomol Z 61 (1): 3-14. DOI: 10.3897/dez.61.7046.

Maneechan W, Prommi TO. 2015. Diversity and distribution of aquatic insects in streams of the Mae Klong Watershed, Western Thailand. Psyche 2015: 1-7. DOI: 10.1155/2015/912451.

Mekong River Commission. 2006. Identification of Freshwater Invertebrates of the Mekong River and Its Tributaries. Mekong River Commission, Vientiane

Melo ALU, Ono ER, Uieda VS. 2020. Benthic invertebrate communities structure in headwater streams with different states of the riparian vegetation conservation. Community Ecol 21: 43-53. DOI: 10.1007/s42974-020-00011-w.

Meyer JD, Strayer DL, Wallace JB, Eggert SL, Helfman GS, Leonard NE. 2007. The contribution of headwater streams to biodiversity in river networks. J Am Water Resour Assoc 43 (1): 86-103.

Morse JC. 2017. Biodiversity of aquatic insects. In: Footit RG, Adler PH (Eds). Insect Biodiversity: Science and Society Vol. 12nd ed. John Wiley and Sons Ltd, New Jersey. 
Morse JC, Frandsen PB, Graf W, Thomas JA. 2019. Diversity and ecosystem services of Trichoptera. Insects 10 (5): 125. DOI: 10.3390/insects10050125.

Morse JC, Yang L, Lixin T. 1994. Aquatic Insects of China Useful for Monitoring Water Quality. Nanjing University Press, Hohai, Nanjing.

Muli A, Lee N, Ling TY, Sim SF, Grinang J. 2019. Macroinvertebrates of the tributaries of upper Baleh river, Sarawak. BJSRT 9 (1): 26-35.

Narangarvuu D, Oyunbileg J, Yang P-S, Boldgiv B. 2014. Distribution of Ephemeroptera, Plecoptera, and Trichoptera assemblages in relation to environmental variables in headwater streams of Mongolia Environ Earth Sci 73 (2): 835-847. DOI: 10.1007/s12665-013-2968 9.

Naser MN, Roy D. 2012. Feeding ecology of Chironomus larvae (Insecta Diptera) collected from different habitat of Dhaka, Bangladesh. Bangladesh J Zool 40 (1): 129-133.

Payakka A, Prommi T. 2014. Aquatic insects biodiversity and water quality parameters of receiving water body. Curr World Environ 9 (1): 53-58.

Polhemus DA, Polhemus JT. 2013. Guide to the aquatic Heteroptera of Singapore and peninsular Malaysia. X. infraorder nepomorphafamilies Belostomatidae and Nepidae. Raffles B Zool 61 (1): 25-45.

Principe RE, Marquez JA, Martina LC. 2019. Distribution and habitat preference of Ephemeroptera and Trichoptera in subtropical mountain streams: implications for monitoring and conservation. Ann Acad Bras Cienc 91 (3): e20180692. DOI: 10.1590/0001 3765201920180692.

Rasdi MZ, Fauziah I, Ismail R, Hafezan MS, Fairuz K, Hazmi AD, Che Salmah MR. 2012. Diversity of aquatic insects in Keniam River, National Park, Pahang, Malaysia. Asian J Agric Rural Dev 2 (3): 312 328 .

Richardson J. 2019. Biological diversity in headwater streams. Water 11 (2): 366. DOI: 10.3390/w11020366.

Righi-Cavallaro KO, Roche KF, Froehlich O, Cavallaro MR. 2010. Structure of macroinvertebrate communities in riffles of a Neotropical karst stream in the wet and dry seasons. Acta Limnol Bras 22 (3) 306-316.

Santana HS, Silva LCF, Pereira CL, Simiao-Ferreira J, Angelini R. 2015. The rainy seasons increases the abundance and richness of the aquatic insect community in a Neotropical reservoir. Braz J Biol 75 (1): 144 151 .

Santos AN, Stevenson RD. 2011. Comparison of macroinvertebrate diversity and community structure among perennial and nonperennial headwater streams. Northeastern Nat 18 (1): 7-26.

Shafie MSI, Wong ABH, Harun S, Fikri AH. 2017. Land use influence on the aquatic insect communities on tropical forest streams of Liwagu River, Sabah, Malaysia. AACL Bioflux 10 (2): 341-352.
Silveira LS, Rosa BFJV, Goncalves EA, Alves RG. 2015. Influence of pools and riffles on Chironomidae diversity in headwater streams of the Atlantic forest. Neotrop Entomol 44: 423-429.

Sudarso J, Wardiatno Y, Setiyanto DD, Anggraitoningsih W. 2013. Effect of anthropogenic activities on Trichoptera larvae community in Ciliwung River. Jurnal Manusia Lingkungan 20 (1): 68-83. DOI: 10.22146/jml.18475. [Indonesian]

Sundar S, Heino J, Roque FO, Simaika JP, Melo AS, Tonkin JD, Nogueira DG, Silva DP. 2020. Conservation of freshwater macroinvertebrate biodiversity in tropical regions. Aquat Conserv 30 (6): 1238-1250.

Suriyawong P, Thapanya D, Bergey EA, Chantaramongkol P. 2018. Aquatic insect functional feeding groups in a mountain stream with a series of check dams in Northern Thailand. Sains Malaysiana 47 (7): 1379-1386.

Takaoka H, Sofian-Azirun M, Yacob Z, Chen CD, Lau KW, Low VL, Suana IW. 2017. The black flies (Diptera: Simuliidae) of the Lesser Sunda Archipelago, Indonesia. Acta Tropica 169: 170-186.

van Bierviliet O, Wisnlewski K, Daniels J, Vonesh J. 2009. Effects of tea plantations on stream invertebrates in a global biodiversity hot spot in Africa. Biotropica 41 (4): 469-475.

Vasanth M, Selvakumar C, Subramanian KA, Rabu R, Sivaramakrishnan KG. 2019. A new record of the Family Isonychiidae (Insecta: Ephemeroptera) from Western Ghats, India with a description of new species. Zootaxa 4586 (1): 162-170.

Wang X, Tan X. 2017. Macroinvertebrate community in relation to water quality and riparian land use in a subtropical mountain stream, China. Environ Sci Pollut Res 24: 14682-14689. DOI: 10.1007/s11356-0179042-1.

Wantzen KM, Yule CM, Mathooko JM, Pringle CM. 2008. Organic matter processing in tropical streams. In: Dudgeon D (Eds). Tropical Stream Ecology. Academic Press, London.

Wesner JS. 2010. Seasonal variation in the trophic structure of a spatial prey subsidy linking aquatic and terrestrial food webs: Adult aquatic insects. Oikos 119 (1): 170-179.

Wong ABH, Fikri AH. 2016. Aquatic insect communities in and around the tropical streams of Kinabalu Park, Sabah, Malaysia. AACL Bioflux 9 (5): 1078-1089.

Xu M, Zhao N, Zhou X, Pan B, Liu W, Tian S, Wang Z. 2018. Macroinvertebrate biodiversity trends and habitat relationships within headwater rivers of the Qinghai-Tibet Plateau. Water 10 (9): 1214. DOI: $10.3390 /$ w10091214.

Yoshimura M. 2012. Effects of forest disturbances on aquatic insect assemblages. Entomol Sci 15: 145-154. DOI: 10.1111/j.14798298.2011.00511.x.

Yule CM, Sen YH. 2004. Freshwater Invertebrates of the Malaysian Region. Academy of Sciences, Malaysia. 